\title{
The Transformation of The Lecturers' Islamic Work Ethos Towards The Quality-Service Culture of Islamic Education in UHAMKA Jakarta
}

\author{
Sri Astuti \\ University of Mubammadiyah Prof. DR. Hamka (UHAMKA) Jakarta \\ Sriastuti99@yaboo.com
}

\begin{abstract}
This research was to describe the level of islamic work ethos, the level of the qualityservice culture of Islamic education, and the transformation of the lecturers' islamic work ethos towards the quality-service culture of Islamic education for the students in UHAMKA. The method used was qualitative with correlation and regression approaches. There were 205 people who became the population and 77 lecturers of FKIP (Faculty of Teaching and Education) UHAMKA who became the samples of the reseach. The Likert-scale questionnaire with five options was used for the instrument of the data collection. The results of the research showed: (1) the lecturers' islamic work ethos belonged to high and satisfying category, (2) the quality-service culture was high and satisfying, and (3) there was a $12.48 \%$ positive and significant transformation of the lecturers' Islamic work ethos towards the quality-service culture of islamic education for the students. The higher Islamic work ethos will lead to the higher transformation of the quality-service culture. The quality-service culture of Islamic education can be improved through Islamic work ethos. A high-quality service of the lecturers gives satisfaction to the students more than they expect.
\end{abstract}

Keywords: Islamic Work Ethos, Quality-service Culture, and Transformation

\begin{abstract}
Abstrak
Penelitian ini bertujuan untuk mendeskripsikan tingkat etos kerja islami, tingkat budaya kualitas pelayanan pendidikan Islam, dan transformasi etos kerja islami dosen terhadap kualitas pelayanan pendidikan Islam bagi mahasiswa di UHAMKA. Metode yang digunakan adalah kualitatif dengan pendekatan korelasi dan regresi. Populasi sebanyak 205 dan sampel 77 dosen FKIP (Fakultas Keguruan dan Ilmu Pendidikan). Instrumen menggunakan Kuesioner dengan skala Likert dengan lima opsi. Hasil penelitian menunjukkan: etos kerja para dosen tinggi dan memuaskan, budaya kualitas pelayanan berkualitas tinggi dan memuaskan, dan transformasi etos kerja islami dosen terhadap kualitas pelayanan pendidikan Islam positif dan signifikan 12,48\% Etos kerja Islam yang lebih tinggi akan menghasilkan transformasi budaya pelayanan-kualitas yang lebih tinggi. Budaya kualitas pelayanan pendidikan Islam dapat ditingkatkan melalui etos kerja Islam. Kualitas Pelayanan dosen yang tinggi akan memberi kepuasan kepada mahasiswa lebih dari yang mereka harapkan.
\end{abstract}

Kata Kunci: Etos kerja Islam, Budaya Kualitas Pelayanan, and Transformasi

Permalink/DOI:http://dx.doi.org/10.18326/infsl3.v11i1.1-24 


\section{Introduction}

The lecturers of Islamic colleges (PTKI) are supposed to have Islamic work ethos because they normally develop Islamic modern intellectuality. Islamic work ethos is a set of business activities in various forms without any limitation of the amount of property (goods/services), but limited by the rules of halal and haram in obtaining and using them (Alimin, 2004:57).

There are several obstacles and unsatisfying conditions related to the Islamic work ethos performed by the lecturers. Here are some complains from the students of IAIN (State Institute of Islamic Religion) Walisongo Semarang: (1) the materials of study were not well-prepared, (2) not attending the classes frequently, (3) not discussing the given assignments and tests, so the students won't know the mistakes they made, (4) difficult to contact or to see when the students want to have consultations or explanations about something. (Jumiatun, 2014: 8). Another result of the research held in IAIN Sultan Thaha Saefudin Jambi shows $40 \%$ of the lecturers still have low Islamic work ethos although other $60 \%$ have high work ethos. (Raudhah \& Muhammad, 2012: 167-182).

Islamic work ethos will be transformed into culture of quality service if it is implemented in the lecturers' academic activities in campus. According to Tilaar (2002:11), in present time, colleges are faced to the fulfilment of quality and accountability for their educational services in order to satisfy the consumers. The ability in giving services to students becomes the main basis to be professional lecturers along with other requirements.

Based on the results of some researches, lecturers' services are still not satisfying the students. Ilyas found (1) unsatisfying academic services, (2) the use of learning media is still 58\%, (3) the referenced books provided by the institutions is 50\%, and (4) the suitability between the learning activities with the plans is still 33\% (Ilyas, 2014: 155-159).

A research conducted by Hamdi showed similar responses. The level of satisfaction of the students of South Aceh Polytechnics, technics of information study program towards lecturers' work 
ethos in learning process, from tangible dimension only $57 \%$ of the respondents who are satisfied with all aspects, from reliability dimension only $54 \%$ of the respondents who are satisfied with all aspects, responsiveness dimension only $53 \%$ of the respondents who are satisfied with all aspects, from assurance dimension only $50 \%$ of the respondents who are satisfied with all aspects, from empathy dimension only $46 \%$ the respondents who are satisfied with all aspects (Hamdi, 2014).

According to those results of the researches, the lecturers have to improve their islamic work ethos in order to develop culture of educational service for the students. By having islamic work ethos, the lecturers can transform the values into the culture of quality service especially for the students. This article tries to find out how the islamic work ethos of the lecturers in UHAMKA have its effects on the culture of quality service of islamic education for the students. University of Muhammadiyah Prof. DR. HAMKA (UHAMKA) is one of private universities that belongs to Persyarikatan Muhammadiyah in Jakarta. It was established on the basis of al-quran and assunah as islamic belief with Pancasila/the five pillars and 1945 Constitution as the foundation. As a Muhammadiyah university, it holds caturdharmathe four points of devotion, holding guidance of devotion and faith to Allah swt, education and teachings, research, and devotion to the community based on islamic principles. (http:// uhamka.ac.id/profil/sejarah, accessed on 06 April 2017)

UHAMKA plays an important role in the process of islamic education for the students because the management of the education is based on islam. The islamic work ethos of the lecturers is important to improve the service of islamic education for students. Therefore, this article will describe: (1) the level of the lecturers' islamic work ethos, (2) the level of quality-service culture of islamic education conducted by the lecturers, and (3) analysis of the islamic work ethos transformation towards the quality-service culture of islamic education in UHAMKA Jakarta. 


\section{Theoritical Foundations}

\section{Transformation}

According to Gunawan, transformation means an effort of transforming a form to a better form. Transformation is a process, stages, or a fast turning point for a change (Gunawan, 1993: 228). Indonesia National Encyclopedia (1991:422) defines the terminology of social transformation as comprehensive changes in form, shape, nature, character, etc, in reciprocal relationship both as individuals and groups. Social transformation involves people, technology, cultural values, and social movement.

Durkheim as quoted by Kuntowijoyo (1996: 3), states transformation can occur because it's inspired by moral spirit, values, or the same belief of the community (collective consciousness), which is formed from a consensus that will affect the life pattern of the community comprehensively. In this case, Islam must be the power that motivates continuously, and transform the community in all aspects into big scale practically and also theoritically.

\section{Islamic Work Ethos}

Islamic work ethos as spiritual ability becomes a demand for the lecturers especially in Islamic Colleges. Spiritual ability is needed to read the signs of the era, so that by using high wisdom, they wil be able to face and handle the fast and continuous changes smartly in human life (Asy'ari, 1997: 35).

At first, ethos is derived from English word "ethos" (John suryani and Kunca, 1985: 12), taken from latin word "ethiko", then changed into ethos (K. Prem C. Mj A.S and WJS Purwadarminta, tt: 292). According to Asyari (1997: 93), ethos means basic attitudes towards one self and their world reflecting basic attitudes of life in working. Ethos according to Abdullah (ed). (1974:3), automatically covers definition and people's or community judgement towards the way someone works, whether he regards his work as a must, or only as a sacred obligation in his self. 
Al-qur'an in surat At-Taubah [9]: 105 confirms that someone has to work to earn his/her needs. As a universal and rabmatan lil'alämin religion, islam surely has normative teachings about islamic ethos. Islamic work ethos should consist of three elements: taubid, takwa, and worship. Alim (1996: 6-7) says work ethos or work spirit of a muslim is a gift from Allah swt. This spirit will only be given to those who are diligent performing prayers, prays, dzikir, and return to Him. This work ethos will be installed in muslim hearts and reflected in four characters: sincere, hard work, creative, and productive.

Islam demands a good work that clears the soul, creates true morality, spreads goodness, tightens humanity relationship, keeps social life, protects ourselves, honors, wealthy, heart, and mind (Luth, 2001: 22-24). When doing good deeds and worships, muslim have to meet some requirements: (1) sincere, is integrating heart and activities motivated for the pleasure of Allah. (2) love, where loving the job is a must, because by doing so, we will get additional benefits in form of spiritual experiences when earning for life. (3) istiqomah (consistent), means keep holding the truth. Since working is a form of worship, it has to be in line with the islamic rules. Don't break the rules when doing the jobs. (4) ready to sacrify time, power, thought, money, and feeling, and accept the test as a worship. (5) expend money in the right way as an expression of grateful for the gifts that Allah has given (Luth, 2001: 22-24).

Didin H. (2003: 40-41) explains four characteristics of Islamic work ethos: (1) al-șalāḅ means good and beneficial, (2) al-itqān means stable and perfectness, (3) al-ibsān means doing the best and better, (4) al-mujāhadah means optimum hard work, (5) tanāfus and ta'āwun means compete and help each other, and (6) concern the value of time. Myrdal (1970: 62) explains 13 atttudes of work ethos: (1) efficient, (2) diligent, (3) regular, (4) discipline or on time, (5) saving, (6) honest and careful, (7) rational in making decision and behaviour, (8) ready to accept changes, (9) agile in using opportunity, (10) energetic, (11) sincerity and confident, (12) cooperative, and (13) visioner. 
Tasmara (2002: 73-124) considers Islamic work ethos covers: (1) addicted to time, (2) sincere morality, (3) honesty, (4) commitment, (5) consistent, (6) disciplin, (7) consequent and brave to face challenges, (8) confident, (9) creative, (10) responsible, (11) happy because serving, (12) self-esteem, (13) leadership, (14) future-oriented, (15) efficient, (16) enterpreneurship, (17) fighting spirit, (18) independent, (19) eager to study, (20) adventurous, (21) care about health and nutrition, (22) tough and never give up, (23) productivity-oriented, (24) enhance relationship web, and (25) have changes spirit.

\section{Quality-service Culture}

Lewis \& Booms in Tjiptono (2004: 121) defines service quality as measurement of how good the given service is and also it meets the costumer expectation. It means that the quality of service can be achieved by fulfiling costumer's needs and wants and the accuration of delivery to balance the costumer expectation. Even more, Parasuraman et.all. in Tjiptono (2004: 121) conveys two main factors that affect the quality of the service: (1) costumers' perception on the perceived service. Quality should start from costumer's needs and end in coostumers' perception. It means that good-quality image is not based on the perception of the service provider, but perception of the costumers, and (2) the expected service. In the quality context of goods and service, and satisfaction, there's a consensus that costumers' expectation has a big role as comparison factor of quality evaluation.

Parasuraman, Zeithaml, and Berry (1998: 12-40), state 10 common dimension of service quality: tangible-physical appearance, reliability-perform as promised constantly, responsiveness, competence, courtesy, credibility, security/safety, access-easy to do business, communication-keeping customer informed, understanding customer needs. In the next development, they are shortened into five main dimensions: tangible, reliability, responsiveness, assurance, and empathy. Meanwhile, Saravanan \& Rao (2007) identify dimension or factors of service quality as follows: human aspects of service delivery, core service, social, responsibility, 
systematization of service delivery: nonhuman aspects, tangibles of service-service scapes, service marketing. More specific, dimension of service quality in the colleges.

Physical evidence is company's ability in showing its existence to external party. It's shown by performance and physical facilities to give services to the costumers. They can be in forms of building, equipments, tools and staff appearances.

Reliability is company's ability in serving as promised accurately and trustfully. Performance should be shown as the costumers expect like time accuration, equal service to all without any mistake, showing sympathy with high level of accuration.

Responsiveness is willingness to give fast and right services to costumers and fast in responding complains. Assurance performed can be in form of knowledge, politeness, and staff's ability to build costumers' trust to the company. This can be seen from communication, credibility, security, competence, and politeness. Empathy is a sincere and individual attention to costumers in order to understand specific needs of the costumers.

Reliabilty dimension relates to the ability to give services as promised accurately and trustfully and reflected in Q.S. an-Nah\}1 [16]: 91. Tangible dimension (physical evidence) or comfortable facilities are important in giving services, but it is not like an over-wealth as stated in Q.S. at-Taka>t\}ur [102]: 1-5. Responsiveness dimension relates to the lecturers' willingness or availability to give fast and right services to the students as stated in a hadist of Rasulullah Saw.

"if a mandate is ignored, then wait for the destruction, a man said: how it is ignored o Rasulullah? He said: if a work is given to an unskillful man, then wait for the destruction". [Hadith from Bukhari]

Assurance dimension relates to knowledge, politeness, self confidence, and respect from the lecturers to the students. Asssurance dimension is stated in Q.S. Ali Imran [3]: 159. Empathy dimension relates to the lecturers' willingness to care and pay attention individually to the students. Concerning empathy, Rasulullah Saw said: 
"Abu Musa al-Asy'ary said: the prophet saw said, a muslim who becomes a mandatable treasurer, who does what is told to him perfectly and happily, give it to those whom he is ordered to, then he belongs to those who gets the reward of shodaqoh." [Hadist from Bukhari-Muslim]

Tampubolon (2001: 122-124) mentions the main components of service quality in the colleges are: (1) relevancy, is suitability between academic policy with the needs of students, government, society, and book supply in the library as curriculum demand, (2) efficiency and effectiveness, are the way of presenting the study materials and the procedure of administration, (3) accountability, is responsibility of the test result, the service of the lecturers and administration, (4) creativity, relates to teaching methods, new literature, and working-world infomation, (5) situation of work, such as relation between the lecturers, supporting staff, and the students, (6) performances, such as tidiness, cleanliness, beauty of the classroom, equipments, and staff-lecturers appearance, (7) empathy and responsiveness: services and responsiveness to costumers, and (8) productivity and ability covering student graduation level every year, students' ability, and the period of waiting for getting a job.

\section{Method of the research}

This is a associative survey research with regression analysis and correlation. Associative research means research that finds out the relationship between one variable dan another variable (Sugiyono: 1994: 74). Survey research aims at describing the data about the object, but also interprets and compares certain measurement that has been determined (SR Pudjiastuti, 2004: 13). Correlation research aims at detecting how far the varians of a factor are connected to the varians of other one or more factors based on correlation coefficient (S. Suryabrata, 1992: 24).

The reseach design in form of effect correlation among variables is shown in picture 1 : 


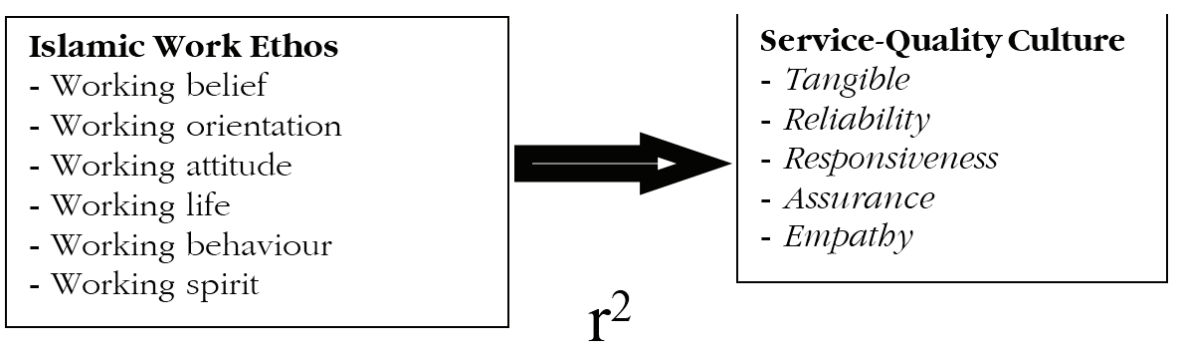

Picture. 1

\section{Research design "The Transformation of the Lecturers' Islamic Work Ethos Towards the Service-Quality Culture of Islamic Education}

The picture shows that islamic work ethos in this research covers working belief, working orientation, working attitude, working life, working behaviours, and working spirit. They will be transformed into service-quality culture held by the lecturers of UHAMKA Jakarta. Meanwhile service-quality culture covers: tangible, reliability, responsiveness, assurance and empathy. The transformation of Islamic work ethos towards the service-quality culture can be seen from determination coefficient (the effect of variable $\mathrm{X}$ on variable $\mathrm{Y}$ ) is $\mathrm{r}^{2}$.

The population of the research was 205 lecturers from Faculty of Teaching and Education Study of UHAMKA Jakarta. The samples of the research were 77 of 125 population or $\pm 38 \%$ of the research samples (Sugiyono, 1998: 112). Slovin formula was used to determine the accuration of samples. The number of samples taken was also based on Suharsimi Arikunto (1992: 10) saying that samples can be taken $20-25 \%$ or more if the total number of samples is bigger. Sample was taken by using Random Sampling technic.

Likert-scale questionnaire was used as the instrument in this research. The instrument of islamic work ethos was based on the view of Toto Tasmara which consisted of working belief, working orientation, working attitude, working life, working behaviour, and working spirit. The instrument of service-quality culture was based on SERVQUAL model (service Quality) Zeithaml and Berry which consisted of: tangible, reliability, responsiveness, assurance, and empathy dimension. 
A try out was held before the use of the instrument. It involved 20 respondents out of the research samples. List of points, validity level and the reliability of the instrument can be seen in table 1 and table 2 .

Table. 1

Validity and Relibility of Islamic Work Ethos Instrument

\begin{tabular}{|c|c|c|c|c|c|c|}
\hline No & Dimension & No of point & Valid point & $\begin{array}{l}\text { Drop } \\
\text { point }\end{array}$ & Validity & Reliability \\
\hline 1 & Working belief & $1,2,3,4,5,6$ & $1,2,3,4,5,6$ & - & $0.481-0.668$ & 0.737 \\
\hline 2 & $\begin{array}{l}\text { Working } \\
\text { orientation }\end{array}$ & $7,8,9,10,11,12$ & $7,8,10,11,12$ & 8 & $0.468-0.645$ & 0.763 \\
\hline 3 & Working attitude & $\begin{array}{c}13,14,15,16,17,18,19,21,22 \\
23,24,25,26\end{array}$ & $\begin{array}{c}13,14,16,17,18 \\
19,20,21,22,23 \\
24,25,26\end{array}$ & $\begin{array}{l}15, \\
21\end{array}$ & $0.449-0.641$ & 0.867 \\
\hline 4 & Working life & $27,28,29,30,31,32,33,34,35$ & $\begin{array}{c}28,29,30,31,32 \\
33,34,35\end{array}$ & 27 & $0.453-0.888$ & 0.836 \\
\hline 5 & $\begin{array}{l}\text { Working } \\
\text { behaviour }\end{array}$ & $\begin{array}{c}36,37,38,39,40,41,42,43,44 \\
45,46,47,48,49,50,51\end{array}$ & $\begin{array}{l}36,37,39,40,41 \\
42,43,44,45,46 \\
47,48,49,50,51\end{array}$ & 38 & $0.483-0.818$ & 0.927 \\
\hline 6 & Working spirit & $52,53,54.55,56,57,58,59,60$ & $\begin{array}{c}.52,53,54,55,56 \\
57,58,59,60\end{array}$ & 53 & $0.445-0.748$ & 0.879 \\
\hline & Overall & 60 & 54 & 6 & $0.453-0.888$ & 0.961 \\
\hline
\end{tabular}

Table 1 shows islamic work ethos consists of six dimension. First dimension, working belief consists of six points. All points, $1,2,3,4,5$, and 6 are valid. Validity level is between 0.481-0,668. Reliability is 0.737 . Second dimension, working orientation consists of six points. Five of them are valid, point 7,9,10,11, and 12. Point 8 is drop. Validity level is between $0.449-0.61$. Reliability level is 0.763 . Third dimension, working attitude consists of 14 points. 12 of them, point $13,14,16,17,18,19,20,22,23,24$ and 25 are valid. Validity level is between 0.449-0.641. Reliability level is 0.867. Fourth dimension, working life consists of nine points. Eight of them, point $28,29,30,31,32,33,34$ and 35 are valid. One point, point 27 is drop. Validity level is between $0.453-0.818$. Reliability level is 0.836 . Fifth dimension, working behaviour consists of 16 points. Fifteen of them, point $36,37,39,40,41,42,43,44,45,46,47,48,49,50$ and 51 are valid. One point, point 38 is drop. Valdity level is between $0.483-0.727$. Reliability level is 0.927 . Sixth dimension, working spirit consists of nine points. Eight of them, point 52,54,55,56,57,58,59 and 60 are valid. One point, point $53 \mathrm{~s}$ drop. Validity level is between 0.445 0.748 . Reliability level is 0.961 .

From table 1, it can be concluded that 54 valid instrument, has moderate validity level between 0.449-0.818, and moderate 
reliability level for each dimension between $0.737-0.927$. While the relibility altogether is 0.961 .

Table. 2

Validity and Reliability of Service-Quality Culture of Islamic Education

\begin{tabular}{clccccc}
\hline No & Dimension & No of point & Valid point & $\begin{array}{c}\text { Drop } \\
\text { point }\end{array}$ & Validity & Reliability \\
\hline 1 & Tangible & $1,2,3,4,5$, & $1,2,3,4,5$, & - & $0.467-0.885$ & 0.719 \\
& Relaibility & $6,7,8,9,10,11$, & $6,8,9,10,11$, & 7 & $0.595-0.994$ & 0.890 \\
& & $12,13,14$, & $12,13,14$ & & & \\
3 & Responsiveness & $15,16,17,18,19$, & $15,17,18,19$, & 16 & $0.526-0.762$ & 0.676 \\
4 & Assurance & $20,21,22,23,24$, & $20,21,22,23,24$ & - & $0.571-0.880$ & 0.794 \\
5 & Empathy & $25,26,27,28$, & $25,26,28,29$, & 27 & $0.469-0.898$ & 0.874 \\
& $29,30,31,32$. & $30,31,32$, & & & & \\
& Overall & 32 & 29 & 3 & $0.467-0.994$ & 0.959 \\
\hline
\end{tabular}

Table 2 shows the instrument of service-quality culture of Islamic education conducted by the lecturers of UHAMKA Jakarta, consists of five dimension. First dimension tangible consists of five points. All points, 1,2,3,4,5 are valid. Validity level is between $0.467-0.885$. Reliability level is 0.719 . Second dimension, reliability consists of eight points. Seven of them, point $6,8,9,10,11,12,13$ and 14. One point, point 7 is drop. Validity level is between $0,595-0,994$. Reliability level is 0.890 . Third dimension, responsiveness consists of five points. Four of them, point 15,17,18, and 19. One point, point 16 is drop. Validity level is between 0,526-0,762. Reliability level is 0.676 . Fourth dimension, assurance consists of five points. All points, 20,21,22,23 and 24 are valid.Validity level is between 0.571-0.880. Reliability level is 0.794. Fifth dimension, empathy consists of eight points. Seven of them, point 25,26,28,29,30,31 and 32 are valid. One point, point 27 is drop. Validity level is between $0.469-0.898$. Reliability level is 0.874 .

Table 2 also shows that validity level of each indicator is moderate between $0.467-0.994$. The reliability of the indicators is also moderate between 0.676-0.896, and altogether instrument reliability belongs to high level, which is 0.959 . 
This research uses descriptive and inferensial data analysis. According to Darwyan, et.all (1996: 3), descriptive analysis means statistics whose function is only to organise, analyse, and explains the data (condition, symptom, problem) in numbers to get organised, brief, and clear description. While inferensial analysis covers regression and simple correlation. According to A. Pratisto (2009: 81), correlation analysis is always adhered to regression analysis, because if independent variable (X) has a real effect on dependen variable $(\mathrm{Y})$ or has a strong correlation, so automatically all changes on $\mathrm{X}$ will be very influencial to $\mathrm{Y}$. Regression analysis is used to predict in which there is a dependent variable and independent variable.

\section{Analysis of the Research Findings}

\section{Islamic Work Ethos}

The level of the lecturers' Islamic work ethos in Faculty of Teaching and Education (FKIP) UHAMKA Jakarta covers: working belief, working orientation, working attitude, working life, working behaviour, and working spirit. The description is in Table 3 as follows:

Table. 3

The Level of Islamic Work Ethos

\begin{tabular}{lllll}
\hline No & Dimension & Mean & $\begin{array}{l}\text { Standard } \\
\text { Deviation }\end{array}$ & Interpretation \\
\hline 1 & Working belief & 3.79 & 0.97 & High \\
\hline 2 & Working orientation & 3.83 & 0.93 & High \\
\hline 3 & Working attitude & 3.94 & 0.97 & High \\
\hline 4 & Working life & 4.25 & 0.84 & High \\
\hline 5 & Working behaviour & 4.53 & 0.50 & High \\
\hline 6 & Working spirit & 4.29 & 0.72 & High \\
\hline & Overall & 4.10 & 0.82 & High \\
\hline
\end{tabular}

Table 3 shows the level of Islamic works ethos that reaches the highest point in Working behaviour dimension $($ mean $=4.53$, standard deviation $=0.50$ ) high category, followed by Working 
spirit dimension $($ mean $=4.29$, standard deviation $=0.72)$ high category, Working life dimension (mean $=4.25$, standard deviation $=0.84$ ) high category, Working attitude dimension (mean $=3.94$, standard deviation $=0.97)$ high category, Working orientation dimension $($ mean $=3.83$, standard deviation $=0.93$ ) high category, and Working belief dimension $($ mean $=3.79$, standard deviation $=$ 0.97) high category. And overall the Level of Islamic work ethos is high $($ mean $=4.10$, standard deviation $=0.82)$.

\section{Service-Quality Culture of Islamic Education}

The level of the lecturers' service-quality culture of islamic education in Faculty of Teaching and Education UHAMKA Jakarta covers tangible, reliability, responsiveness, assurance and empathy as described in Table 4 below:

\section{Table. 4}

The Level of Service-Quality Culture

\begin{tabular}{llccc}
\hline No & Dimension & Mean & $\begin{array}{c}\text { Standard } \\
\text { Deviation }\end{array}$ & Interpretation \\
\hline 1 & Tangible & 3.60 & 1.04 & Moderate \\
\hline 2 & Reliability & 3.99 & 0.89 & High \\
\hline 3 & Responsiveness & 4.39 & 0.75 & High \\
\hline 4 & Assurance & 3.66 & 0.98 & Moderate \\
\hline 5 & Empathy & 4.37 & 0.76 & High \\
\hline & Overall & 4.01 & 0.89 & High \\
\hline
\end{tabular}

Overall, the service-quality culture of the lecturers reaches the highest point in empathy dimension $(($ mean $=4.37$, standard deviation $=0.76)$ high category, followed by responsiveness dimension $($ mean $=4.39$, standard deviation $=0.75)$ high category, reliability dimension $($ mean $=3.99$, standard deviation $=0.89)$ high category, assurance dimension $($ mean $=3.66$, standard deviation $=$ 0.98 ) moderate category, tangible dimension (mean $=3.60$, standard deviation $=1,04)$ moderate category. And the service-quality culture altogether is high $($ mean $=4.01$, standard deviation $=0.89)$. 


\section{Requirement Analysis Testing}

Regresion and correlation analysis was used in this research to test the hypothesis. Statistics parametric requirement testing is needed before the hypothesis testing so that the result of correlation and regression analysis can be used to take the general conclusion. The requirement testing was normality test, linearity and significance test.

Normality test was applied to each variable to recognise if the data had normal distribution by using error estimation technic $\mathrm{Y}$ on $\mathrm{X}$. By using that analysis, it is found that $\mathrm{L}_{\mathrm{o}}$ is smaller than $\mathrm{L}_{\mathrm{t}}$. Therefore, it can be concluded that the data of Islamic work ethos and the service-quality culture is normal. The calculation result of normality test can be seen in Table 5 as follows:

Table. 5

\section{Summary of Data Normality Test Analysis}

\begin{tabular}{ccccc}
\hline NO & Error estimation & $\mathrm{L}_{\text {calculate }}$ & $\mathrm{L}_{\text {table }}$ & Note \\
\hline \hline 1 & Y on X & 0,099 & 0,101 & Normal \\
\hline
\end{tabular}

Table 5 shows normality test of the data transformation of islamic work ethos towards service-quality culture $\mathrm{L}_{\text {calculate }}=0,099$ $<0,101=\mathrm{L}_{\text {table }}$. Because $\mathrm{L}_{\text {calculate }}$ is smaller than $\mathrm{L}_{\text {table, }}$, so the data of islamic work ethos and service-quality culture of islamic education is normally distributed. Then linearity test and significance test were held. Those tests were based on ANAVA (varian analysis ) table. Analysis on various source of varian is displayed in table 6 as follows:

Table 6

Anava for Simple Linear Regression $\hat{Y}=181.96+0.37 X_{1}$

\begin{tabular}{llllll}
\hline Su.Va & Db & JK & RJK & Fh & Ft \\
\hline Total & 77 & 3917670.00 & & & \\
Reg a & 1 & 3912989.14 & 3912989.14 & & \\
Reg b & 1 & 583.95 & 583.95 & 10.69 & 3.98 \\
Remain & 75 & 4096.91 & 54.63 & & \\
Tu match & 26 & 1757.56 & 67.60 & & \\
Error & 39 & 2339.35 & 59.98 & 1.13 & 1.80 \\
\hline
\end{tabular}


Table 6 shows the result of linearity test Fcalculate is 1.13 while from the $\mathrm{F}$ distribution list with the level of significance $\alpha=$ 0.05 , degree of freedom $\mathrm{db} 1=26$ and $\mathrm{db} 2=39$ it is found that $\mathrm{F}_{\text {table }}$ is 1.80. If we compare both of them, $\mathrm{F}_{\text {calculate }}<\mathrm{F}_{\text {table }}$ or $1.13<1.80$. It can be concluded that the regression $\hat{Y}=181.96+0.37 X_{1}$ is linear.

After linearity test, the sgnificance test was conducted. From the ANAVA analysis table, it is found that $\mathrm{F}_{\text {calculate }}=10.69$ while from the $\mathrm{F}$ distribution table with degree of freedom $\mathrm{db}_{1}=1$ and $\mathrm{db}_{2}=$ 68 , and degree of trust $\alpha=0,05$, it is found that $F_{\text {table }}$ 3.98. If both of them are compared, $\mathrm{F}_{\text {calculate }}>\mathrm{F}_{\text {table }}$ atau $10.69>3.98$, so $\mathrm{H}_{0}$ is rejected and $\mathrm{H}_{1}$ is accepted. Therefore, it can be concluded that regression coefficient is significant.

\section{Hypothesis Testing}

Hypothesis Testing with correlation test between Islamic work ethos and service-quality culture is shown in Table 7.

\section{Table 7}

\section{The Significance of product moment correlation}

\begin{tabular}{cccccccc}
\hline $\mathrm{N}$ & $\alpha$ & $\mathrm{r}_{\text {calculate }}$ & $\mathrm{r}^{2}$ & $\mathrm{r}_{\text {table }}$ & $\mathrm{T}_{\text {calculate }}$ & $\mathrm{t}_{\text {table }}$ & Decision \\
\hline 30 & 0.05 & 0.35 & 0.1248 & 0.213 & 3.25 & 1.67 & $\mathrm{H}_{1}$ accepted \\
\hline
\end{tabular}

Based on the analysis of simple correlation, it $i$ found that correlation coefficient $r_{\mathrm{y}}=0.35$ and determination coefficient $r_{\mathrm{y}}^{2}=$ 0.1248 . So the transfomation of islamic work ethos towards servicequality culture is $12.8 \%$. From correlation significance test, it is found that $t_{\text {calculate }}=3.25$. After being tested by t test, it is found that the simple correlation coefficient is significant. It is seen from $\mathrm{t}_{\text {calculate }}>\mathrm{t}_{\text {table }}$ or $3.25>1.67$ at $\alpha=0.05$ and degree of freedom 73 . Relationship between variable $\mathrm{X} 1$ and $\mathrm{Y}$ patterned in the regression can be visualised in diagram of linear regression line as shown in picture 2 . 


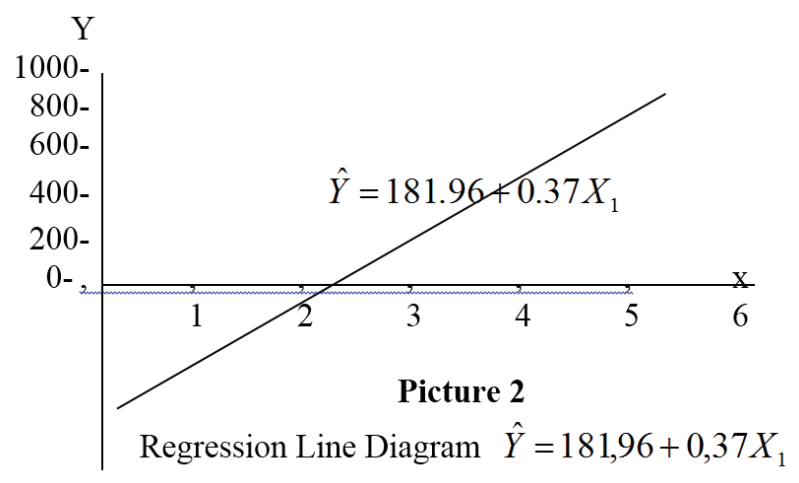

The pattern of relationship between two variables is stated in the linear regression equation $\hat{Y}=181.96+0.37 X_{1}$. This equation informs us that the average change of one score of islamic work ethos is followed by transformation of one score unit of lecturers' service-quality culture which is 0.37 . Then it can be concluded that the higher islamic work ethos the higher transformation of lecturers' service-quality culture and vice versa the lower islamic work ethos the lower transformation of lecturers' service-quality culture.

\section{Discussions}

Lecturers' Islamic Work Ethos

This research finds the lecturers' Islamic work ethos in Faculty of Teaching and Education of UHAMKA Jakarta belongs to high category for all dimension, (1) working belief which covers: consistent or strong belief and happy because of serving, (2) working orientation which overs: future orientation and productivity orientation, (3) working attitude which covers: honesty, discipline, consequent, and brave in facing challenges, self confidence, responsible, having self esteem, independent, (4) working life which covers: enterpreneurship, competitiveness, and leadership, (5) working behaviours which covers: addicted to time, having sincere morality (clean), commitment, creative, saving and efficient, eager to study, enrich the network of reationship, and care about health (nutrition), and (6) working spirit which covers: spirit of adventure, tough, and never give up. 
Islamic work ethos of the lecturers of UHAMKA Jakarta is in line with the concept of tajìd conveyed by Rais (1998:53), changing the work ethos to be more quranic, hard work, honest, discipline, and respect time, as stated in the holy quran. High Islamic work ethos can also be found in IAIN (State Institute of Islamic Religion) Raden Intan Fatah Palembang. According to Yudiani (2016:1-15), the Islamic work ethos of the lecturers in IAIN Raden Fatah covers: integrity, visioner, innovative, professional, nice, and useful, the result is $25 \%$ of the lecturers still have low work ethos eventhough other $75 \%$ of the lecturers have high Islamic work ethos.

The lecturers of Islamic colleges are supposed to have Islamic work ethos. This is to balance the individual dimension and social justice and participation which means every muslim must be active, creative, and productive in the community and enable other people to be participative (Muzairi, 1994: 100).

\section{Service-Quality Culture of Islamic Education}

The result of this research shows that the service-quality culture of Islamic education of the lecturers in UHAMKA Jakarta is vary where the tangible and assurance dimension belong to moderate category while the reliability, responsiveness, and empathy belong to high category. And overall dimension are high.

The various results of the service-quality culture of Islamic education of the lecturers show that: academic services regarded very satisfying by the students from the highest part respectively are: lecturers' material mastery $75 \%$, lecturers' performace in college activities 58\%, lecturers' acceptance to the students 50\%. Academic services regarded satisfying -but still not optimum yet- by the students from the highest part respectively are: lecturers' attendance in campus 67\%, lecturers' understanding on students' condition, suitability between college activities wih the plans, evaluation and feedback 58\%, syllabus availability and college activities plans, lecturers' appreciation on students' ideas and the use of the newest research findings 42\%, needs improving, books availability and guidance are not optimum yet (Ilyas, 2014: 155-159). 
Other research findings show lecturers' service-quality culture of Islamic education in reliability aspect scored 3.98, is satisfying enough. Responsibility aspect scored 4.13, is satisfying enough. Tangible aspect scored 4.14, is satisfying enough. Assurance aspect scored 4.15, is satisfying enough. The average score is 4.09, satisfying enough (Suyoto and Agung, 2014: 36-55).

Overall the service-quality culture of Islamic education performed by the lecturers belongs to high category. This is in line with the concept of service quality saying that basically costumers want beyond-expectation services. As conveyed by Tjiptono dan Gregorius (2005: 121), that service quality is a measurement of how good the service can meet the costumers' expectation.

\section{The Transformation of Lecturers' Islamic Work Ethos Towards Service-Quality Culture of Islamic Education}

The research findings show that the lecturers have conducted transformation from their Islamic work ethos towards service-quality culture of Islamic education as much as $12.43 \%$. These findings are in accordance with Indica's research (2013) that shows relationship between positive and significant effects of islamic work ethos towards the commitment of staff's organisation and work. According to Alim (1996: 6-7), islamic work ethos planted in a muslim heart will be reflected in four characteristics: sincere, hard work, creative, and productive.

This indicates that lecturers have transformed Islamic work ethos into working belief dimension which are service, full of commitment, consistent, independent, and productive working orientation into service culture for the students. Transformation can be seen from working morality, creative, responsible, care about health (nutrition), and working spirit, study and keep learning which transformed into tangible culture of service quality.

Work ethos in upholding honesty, discipline, saving, effiecient, consequent in facing challenges, creative and responsible transformed into reliability culture of service quality. Work ethos in happy service, commitment, consistent, future working orientation 
and productive transformed into responsiveness culture of service quality.

Work ethos in working belief about commitment, future working orientation, learning spirit, and creative working attitude transformed into assurance culture of service quality. Islamic work ethos in productivity working orientation, morality, honesty, enrich relationship, consequent, leadership, service belief, commitment and conistent transformed into empathy culture of service quality.

Transformation of Islamic work ethos towards service-quality culture of Islamic education performed by the lecturers of FKIP UHAMKA is relevant to the concept that Islamic teachings are the sources of activity for structural transformation and form the system of members' behaviours of the community related to socialeconomy phenomena (S.E. Swasono, dkk, 1988: 51). That's why high work ethos is always related to good behaviours. Because there's a transcedental target in good behaviours rather than just worldly life goals. (Mulyadi, 2008: 1-19).

Perceptions above are in line with Sabiq's that Islam demands good work which can clean soul, create straight morality, spread goodness, tightened humanity relationship, keep social life, protect ourselves, dignity, property, heart, and clean mind, Sayyid Sabiq (1991: 156). Good Islamic work ethos refers to surah al-Dluha because of three reasons, (1) we have to be future oriented, (2) optimistic for future victory as the rewards from our work, and (3) we have to be modest and not to be arrogant.

Transformation of Islamic work ethos towards service-quality culture of Islamic education runs on the basis of social action, justice, and participation (students and lecturers). This it to balance individual dimension and social justice and people participation which mean every muslim must be active, creative, and productive in social life and enable other people (students) to be participative (Muzairi, 1994: 100).

Transformation of Islamic work ethos towards tangible culture of service quality lead the lecturers to use interesting learning strategy. Lecturers use attractive teaching aids/media. Lecturers use 
clear language, interesting, and easy to understand and clear voice in explaainig the lessons. Lecturers have attractive performance and dress neatly and politely.

Transformation of Islamic work ethos towards reliability culture of service quality lead lecturers to be expert in explaining study system, reference, rules, and evaluation and task system in the first meeting, conveying rules, on time attending and finishing the lessons, good in explaining the materials, right in giving the assignments and feedback, choosing teaching method, giving easy notes and understand the materials, discipline and transparent, giving suitable assignments to understand the given materials.

Transformation of Islamic work ethos towards responsiveness culture of service quality lead lecturers to be responsive in answering students' questions. Lecturers motivate students' interest and spirit in learning. Lecturers grow enjoyable learning atmosphere. Lecturers have consultation schedule. Lecturers are responsive in answering and solving students' problems.

Transformation of Islamic work ethos towards assurance culture of service quality guarantees lecturers to master and give the lessons well. Lecturers give back students' answer sheet. Lecturers have scoring standard. Lecturers collect test scores on time. Lecturers have sufficient scientific works like journal article and books for learning references.

Transformation of Islamic work ethos towards empathy culture of service quality makes lecturers care about students' progress. Lectures help students solve their problems. Lecturers appreciate students' good answer or give advice for them. Lecturers are nice in serving the students. Lecturers know students' names. Lecturers guide and understand students' needs and behaviours. And lecturers give additional consultation out of college schedule.

Lecturers' quality culture is in line with Islamic teachings, as stated by Sinamo (2011:34) that there are eight professional work ethos: (1) working is a bless, work sincerely, and thankful, (2) working is a mandate, right, and responsible, (3) working is a call, finished, and full of integrity, (4) working is actualisation, hard 
work, and full of spirit, (5) working is worship, serious, and full of devotion, (6) working is art, smart, and creativity, (7) working is honour, keen, and full of superiority, (8) working is service, perfect, and full of modesty.

Therefore, transformation of Islamic work ethos towards service-quality culture of Islamic education is in accordance with Islamic transformation in which basically is a cultural movement on the basis of humanity, liberalisation, and prophetic transcendency, which is changing the history of people's life by their own selves into more participative, open, and emancipatory (Kuntowijoyo, 1994: 65-78). This service-quality culture is in line with Islamic teachings as stated in surat al-Maidah [5]: 2 and QS al-Qashas [28]: 77.

\section{Conclusions}

Islamic work ethos of the lecturers in UHAMKA Jakarta covers aspects of working belief, working orientation, working attitude, working life. Working behaviour, and working spirit. All aspects belong to high category. Service-quality culture of islamic education of the lecturers covers tangibel and assurance dimension belong to high category while reliabilty, reponsiveness, and empathy dimension belong to high category. Overall the quality culture is high. The lecturers of UHAMKA Jakarta have transformed Islamic work ethos into service-quality culture of islamic education as much as $12.48 \%$. The higher islamic work ethos performed by the lecturers, the higher transformation towards service-quality culture.

Islamic work ethos of working belief, orientation, attitute have to be improved. Because the score is low in moderate level. In general needs to be improved because it doesn't reach the ideal score yet, only close to the ideal score. Service-quality culture of the lecturers on tangible and assurance aspects have to be improved because it's still in moderate level. Reliability, responsiveness, and empathy aspects in general, also have to be improved because they are still in low group of high category. Lecturers have to improve the transformation of Islamic work ethos towards the servicequality culture of Islamic education for the students. It is because 
the percentage of transformation of Islamic work ethos towards the service-quality culture of Islamic education is under $15 \%$.

\section{References}

Abdullah, Taufik, (ed). 1974. Agama Etos Kerja dan Perkembangan Ekonomi, Jakarta: LP3ES.

Alim, Sahirul. 1996. Etos Kerja Yang Islami dalam Era Globalisasi, Yogyakarta: Training Mahasiswa UII.

Alimin,2004. Etika \& Perlindungan Konsumen dalam Ekonomi Islam, Yogyakarta: BPFE.

Arikunto, Suharsimi. 1992. Prosedur Penelitian Suatu Pendekatan Praktek, Jakarta: Rineka Cipta.

Asy'ari, Musa. 1997. Islam, Etos Kerja dan Pemberdayaan Ekonomi Umat, Yogyakarta: LESFI.

Ensiklopedi Nasional Indonesia, 1991. Jilid 16. Jakarta: PT. Cipta Adi Pustaka.

Gunawan, Ryadi. 1993. Transformasi Sosial Politik: Antaran Demokratisasi dan Stabilitas, dalam M. Masyhur Amin(ed), Agama, Demokrasi dan Transformasi Sosial, Yogyakarta: KPSM.

Gunnard Myrdal, Gunnard. 1970. An Approach to the Asian Drama, New York: Vintage Books.

Hafidhuddin, Didin dan Tanjung, Hendri. 2003. Manajemen Syari'ah dalam Praktik, Jakarta: Gema Insani Press, First edition.

Hamdi, Nurul. 2014. Model Tingkat Kepuasan Mahasiswa Terhadap Kinerja Dosen Berdasarkan Fuzzy Tahan. Jurnal Samudra Universitas Samudra Aceh, 8 (1)

Ilyas. 2014. Tingkat Kepuasan Mahasiswa Terhadap Layanan Akademik dosen Pendidikan Agama islam (A Research on the Second-Semester Students of Faculty of Education, Semarang State University) Jurnal Penelitian Pendidikan, 31 (2).

Indica, I Wayan Marsalia. 2013. Pengaruh Etos Kerja Islami dan Gaya Kepemimpinan Transformasional Terhadap Komitmen Organisasional dan Kinerja Karyawan (Studi Pada Waroeng Stike dan Shake di Kota Malang. Jurnal Ilmiah Mahasiswa Fakultas 
Ekonomi dan Bisnis: Universitas Brawijaya Malang, 1 (2).

John, Suryani dan Kunca, 1985. Kamus Lengkap Edisi Baru, InggrisIndonesia, Jakarta: Indah.

Jumiatun. 2014, Analisis Pengaruh Motivasi dan Etos Kerja Islami Terhadap Kinerja Pengajaran Dosen (Studi pada Dosen Pengajar Fakultas Ekonomi dan Bisnis Islam). Undergraduate (S1) Thesis, Universitas Islam Negeri (UIN) Walisongo Semarang.

Kuntowijoyo. 1993. Paradigma Islam, Interpretasi Untuk Aksi, Bandung: Mizan.

Kuntowijoyo. 1994. Identitas Politik Umat Islam, Bandung: Mizan.

Luth, Thahir. 2001. Antara Perut dan Etos Kerja dalam Perspektif Islam, Jakarta: Gema Insani Press.

Mulyadi, Acep. 2008. Islam dan Etos Kerja: Relasi Antara Kualitas Keagamaan dengan Etos Produktivitas Kerja di Daerah Kawasan Industri Kabupaten Bekasi. Turats Jurnal Pemikiran dan Peradaban Islam Universitas Islam "45" Bekasi, 4 (1), June.

Muzairi. 1994. Refleksi Tipologis Terhadap Kerja, Journal al Jamiah IAIN Sunan Kalijaga Jogyakarta, No.57.

Parasuraman, A., Zeithaml, V. A., and Berry, L.L. 1988. SERVOUAL: A Multiple-Item Scale for Measuring Consumer Perceptions of Service Quality. Journal of Retailing, 64 (1).

Pratisto, Ahmad. 2009. Statistik Menjadi Mudah dengan SPSS 17, Jakarta: Elekmedia Komputindo.

Pudjiastuti, Sri Rahayu. 2004. Metode Penelitian Pendidikan, Jakarta: STKIP Kusuma Negara.

Rais, M. Amin. 1998. Tauhid Sosial, Bandung: Mizan.

Raudhoh \& Muhammad, Habib. 2012. Pengaruh Sertifikasi dan Etos Kerja Terhadap Kinerja Dosen: Studi Ex Post Facto di IAIN Sulthan Thaha Saifuddin Jambi. Media Akademika IAINJambi, 27 (2), April.

Sabiq, Sayyid. 1991. Unsur- Unsur Dinamika dalam Islam. (terj). Haryono S. Yusuf, Jakarta: PT Internusa.

Santoso, Singgih. 2002. SPSSS Versi 10. Mengolah Data Statistik Secara Profesional, Jakarta: Elekmedia. 
Saravanan R. and Rao KSP. 2007. Service Quality from the Customer's Perspective: An Empirical Investigation. The Quality Management Journal, 14 (3). Milwaukee: American Society for Quality.

Sinamo, Jansen H. 2011. Delapan Etos Kerja Profesional, Jakarta: Institut Mahardika.

Subrata, Adi K. Prem C. MJ. dan Purwadarminta, tt. WJS, Kamus Latin Indonesia, Jakarta: Kanisius.

Sugiyono. 1994. Metodologi Penelitian Administrasi, Bandung: Alfabeta.

Suryabrata, Sumadi. 1992. Metodologi Penelitian Pendidikan, Jakarta: Bumi Aksara.

Suyoto dan Miftahuddin, Agung. 2014. Mengukur Kepuasan Mahasiswa Berdasarkan Kinerja Dosen dalam Proses Perkuliahan. (Studi Empiris di Universitas Muhammadiyah Purwokerto)." Sainteks XI (2) Oktober.

Swasono, Sri Edi, dkk. 1998. Sekitar Kemiskinan dan Keadilan Dari Cendikiawan Kita Tentang Islam, Jakarta: Penerbit UI.

Syah, Darwyan, Supardi dan Hasibuan, Abdul Azis. 1996. Pengantar Statistik Pendidikan, Jakarta: IUN Pres.

Tampubolon. 2001. Perguruan Tinggi Bermutu Paradigma Baru dan Manajemen Pendidikan Tinggi Menghadapi Tantangan Abad ke 21. Jakarta: PT Gramedia Pustaka Utama.

Tasmara, Toto.2002. Membudayakan Etos Kerja Islam, Jakarta: Gema Insani Pers.

Tilaar, H.A.R. 2002. Membenahi Pendidikan Nasional. Jakarta: Rineka Cipta.

Tjiptono, Fandy dan Gregorius. 2005. Service Quality Satisfaction, Yogyakarta: Andi.

Tjiptono, Fandy. 2004. Manajemen Jasa. Yogyakarta: Andi Offset.

Yudiani, Ema. 2016. Etos Kerja Islam Dosen Fakultas Ushuluddin dan Pemikiran Islam UIN Raden Fatah Palembang dari Aspek Religiusitas. PSIKIS -Jurnal Psikologi Islami 2 (1) June. 